\title{
Knowledge and Adoption Levels of the Farmers on Direct Seeding among Rice Farmers of Khammam District of Telangana State, India
}

\author{
B. Raja Madhu Shaker*, J. Hemantha Kumar, P. Jagan Mohan Rao, \\ P. Sri Ranjitha, V. Chaitanya and K. Ravi Kumar \\ Krishi Vigyan Kendra, Wyra, Khammam, Telangana State -507 165, India \\ *Corresponding author
}

\begin{tabular}{|l|}
\hline Ke y w o r d s \\
Rice cultivation, \\
Direct seeded rice, \\
Puddled condition, \\
Drum seeder \\
\hline Article Info \\
\hline $\begin{array}{l}\text { Accepted: } \\
18 \text { May } 2020 \\
\text { Available Online: } \\
\text { 10 June } 2020\end{array}$ \\
\hline
\end{tabular}

\section{A B S T R A C T}

\section{Introduction}

Agriculture plays a vital role in India's economy and accounts for 16.00 percent of the country's Gross value Added (GVA) for the year 2018-19 (Source: Annual report 2018-19, Department of Agriculture, 2018). Rice (Oryza sativa L.) is considered as the "global grain". It is the major staple food for more than half of the global population. Rice is the dominant crop of the country as it is grown in almost all the states of the country. The term 'rice is life' is most appropriate in Indian context as this crop plays vital role in country's food security and is the backbone of livelihood for millions of rural households. It is one of the major cereal crops cultivated in more than 110 countries in the world with a 
total production of 527 million tones, of which 78.00 percent is contributed by the major rice growing countries of Asia (Chandima et al., 2013). India is the largest grower of rice in the world and it occupies the largest cropped area of $44.2 \mathrm{M}$ ha with a total production of 112.91 Million tones with an average productivity of $2578 \mathrm{~kg}$ per hectare (Source: Annual report 2018-19, Department of Agriculture, 2018). However, it ranks second to China in terms of production. In Telangana rice is the major food crop grown in an area of 28.03 lakh ha in kharif and 15.84 lakh ha in rabi with an average productivity of $2404 \mathrm{~kg} \mathrm{ha}^{-1}$. (Source: Annual report 201819, Department of Agriculture, 2018) Rice is the principle food crop cultivated throughout the Telangana state, providing food for the growing population, fodder to the cattle and employment to the rural masses (Chandrashekara et al., 2013).

In Khammam district, majority of the farmers follow conventional method of cultivating rice i.e., transplanting of rice under tanks and canals as source of irrigation. The weather being the major aberration in the district and due to vagaries of monsoon, rains are delayed which further aggravates the labour demand situation. Hence receipt of water under canals and tanks is seen in the second week of August or much later, as a result farmers face water shortage, delayed and limited release of irrigation water from canals is observed. Most of the farmers take up nurseries from June last week in anticipation of rain water and as rains are delayed over-aged seedlings are transplanted on receipt of water and there is frantic and high demand for labour for transplanting and other agricultural operations. Under conditions of late onset of monsoon and insufficient water in canals, water supply being erratic ultimately leads to delayed transplanting. Due to deficit monsoon, delayed and limited release of water from reservoirs farmers do not get sufficient water at right time and they have to complete transplanting within a short time of water availability. Further, Govt. of Telangana has taken up major irrigation projects and they are progressing towards completion. This will result in area under paddy to increase and demand for labour further increases, hence alternate means which eases demand as well as a technology which increases water use efficiency need to be well sought for sustaining paddy productivity. Rice growers are increasingly facing water crisis for traditional rice cultivation and increasing labour cost challenges. Transplanting of rice entails adequate land preparation both for nursery and main field, consumes $20 \%$ of the total water requirement $\mathrm{ha}^{-1}(1240 \mathrm{~mm})$ and requires 25 to 30 man days for its establishment manually depending on soil type. Further, rapid withdrawal of labour from the agricultural sector, increased competition for water and labour have contributed to the current situation and may worsen in the future. Therefore, the sustainability of production in rice fields is severely dented and the ability to increase production in pace with population growth with reduced water and labour use are major concerns. In this contest, KVK, Wyra endeavored to develop direct seeding of rice using drum seeder and has been promoting this method since last 4-5 years. The present study was to find out the Knowledge and Adoption of the farmers on Direct Seeding.

\section{Materials and Methods}

The present study was undertaken during 2018-19 in Khammam district of Telangana. The survey for this purpose was conducted in Khammam district. This study is based on primary data collected from rice farmers. Random sampling technique was adopted in designing sampling frame for the study. Telangana state is selected purposively. In the 
second stage, Khammam district was selected. Accordingly, in third stage six villages were selected randomly based on potentiality. From each of the selected villages, twenty number of rice growers i.e. 120 rice growers were considered for the present study. The Primary data was collected from the farmers through personal interview with the help of well prepared pre-tested schedules and questionnaire. These farmers were classified into different categories based on their land holding i.e. marginal (up to $1.00 \mathrm{ha}$ ), small (1.01 ha to $2.00 \mathrm{ha}$ ) and Big farmers (above 2 ha).

\section{Results and Discussion}

The results obtained from the present investigation as well as relevant discussions have been summarized below

It is evident from Table 1 that nearly 44.17 percent of the respondents selected were in the middle age group, 65.83 percent of the respondents were educated upto high school or had acquired higher studies than that. Nearly 48.34 percent of the rice farmers selected was under small farm size followed by farming experience of 8-14 years for 55.84 percent of the respondents. These selected farmers, 45.00 percent also maintained high extension contact for agricultural information and advisories from Scientists and department officials.

\section{Knowledge levels of rice farmers on Drum seeder technology}

It can derived from Table 2 that analysis of the knowledge items on drum seeding in rice showed that Pre-germinated paddy seed are sown with drum seeder after draining standing water ranked 1st with 84.17 percent of the farmers in the selected area, Drum seeder is a drudgery reducing tool, easy to use, convenient and resulted in shift of work of women to men and Saves 2-3 irrigations compared to conventional method of transplanting ranked $2^{\text {nd }}$ consecutively with 83.33 percent of the respondents having knowledge on this. Further Weedicide is a must in direct sowing using drum seeder in puddle fields ranked as $4^{\text {th }}$; Seed are soaked in water for $24 \mathrm{~h} \&$ incubation in gunny bags for 24-48 hours as $5^{\text {th }}$ respectively. The above results shows that farmers were well informed about drum seeder technology due to good education levels, middle age group having medium farming experience with small farm holdings and high extension contact for technical advice. The findings are in conformity with the results of Visalakshi and Sireesha (2016).

The Knowledge levels of the farmers reveal that On farm trials, FLD's, training programmes, field days and exposure visits organized by KVK technical staff in the villages has created impact in terms of knowledge levels of farmers. This might be due to the reason that it is easy, convenient to use, involves less cost on seed, less labour requirement, water saving, higher yield and more net profit in direct seeding using drum seeder than conventional transplanting.

\section{Adoption of recommended practices in drum seeding by rice farmers}

It can be indicated from Table 3 that the component wise analysis of adoption of the practices of drum seeder technology reveal that more than 50.00 percent of the farmers have adopted levelling of the field, draining out excess water before sowing, more than 60.00 percent of the farmers adopted seed rate, sowing of seed for 24 hours and sprouting of the seed for another 24 hours as these practices are most crucial and farmers felt that these practices contribute for more yield advantages, nearly 50.00 percent of the respondents followed pre and post emergence 
herbicide application. The farmers felt that weed is the major problem in management of rice under direct sown conditions with drum seeder. Nearly 40.00 percent of the farmers adopted fertilizer application, water management, pest and disease management with slight deviations from the recommended practices of the technology.

\section{Extent of adoption of Drum seeder technology by Rice farmers}

Table 4 indicated that 50.00 per cent of the respondents belonged to high adoption category, followed by 32.50 per cent and 17.50 per cent of the respondent belonged to medium and low adoption categories of drum seeder technology in paddy cultivation respectively. Majority $(50.00 \%)$ of the respondents had high level of adoption of due to the fact that farmers adopt the whole package of practices of the drum seeder technology as per the recommendations of the scientists of KVK and Department of agriculture. High rate of adoption is with reference to the component practices of the technology adopted by the farmers and low rates of adoption referrers to the partial adoption of the technology. Further the constraints faced by farmers in paddy cultivation like labour scarcity, drudgery involved in farm operations made the farmers eager to know the technology about drum seeder and opt for its implementation.

Table.1 Profile of the Rice growers selected for the study

$\mathrm{N}=120$

\begin{tabular}{|c|c|c|c|}
\hline S. No & Variables & Category & Frequency \& Percentage \\
\hline \multirow[t]{3}{*}{1} & \multirow[t]{3}{*}{ Age } & Young (22-37) & $29(24.17)$ \\
\hline & & Middle (38-53) & $53(44.17)$ \\
\hline & & Old (54-69) & $38(31.66)$ \\
\hline \multirow[t]{7}{*}{2} & \multirow[t]{7}{*}{ Education } & Illiterate & $09(7.50)$ \\
\hline & & Primary school & $13(10.83)$ \\
\hline & & Upper school & $19(15.83)$ \\
\hline & & High school & $28(23.33)$ \\
\hline & & Intermediate & $37(30.84)$ \\
\hline & & Degree & $09(7.50)$ \\
\hline & & Post graduation & $05(4.17)$ \\
\hline \multirow[t]{3}{*}{3} & \multirow[t]{3}{*}{ Farm Size } & Marginal(0-2.5) & $29(24.16)$ \\
\hline & & Small(2.5-5) & $58(48.34)$ \\
\hline & & Large ( $5 \&$ above) & $33(27.50)$ \\
\hline \multirow[t]{3}{*}{4} & \multirow[t]{3}{*}{ Farming experience } & Low (0-7) & $22(18.33)$ \\
\hline & & Medium (8-14) & $67(55.84)$ \\
\hline & & High (15-21) & $31(25.83)$ \\
\hline \multirow[t]{3}{*}{5} & \multirow{3}{*}{ Extension Contact } & Low (11-17) & $27(22.50)$ \\
\hline & & Medium (18-25) & $39(32.50)$ \\
\hline & & High (26-33) & $54(45.00)$ \\
\hline
\end{tabular}


Table.2 Knowledge levels of Rice farmers on Direct seeded rice (Drum seeder) $\quad$ N=120

\begin{tabular}{|c|c|c|c|c|}
\hline \multirow[t]{2}{*}{ S.no } & \multirow[t]{2}{*}{ Direct sowing technology practices } & \multicolumn{3}{|c|}{ Knowledge level } \\
\hline & & Frequency & Percentage & Rank \\
\hline $\mathbf{1}$ & $\begin{array}{l}\text { Direct sowing paddy using drum seeder } \\
\text { requires well puddled \& levelled fields }\end{array}$ & 95 & 79.16 & 7 \\
\hline 2 & $\begin{array}{l}\text { Pre-germinated paddy seed are sown with drum } \\
\text { seeder after draining standing water }\end{array}$ & 101 & 84.17 & 1 \\
\hline 3 & $\begin{array}{l}\text { If there is more standing water in the field, } \\
\text { leave the field for 1-2 days for settling of } \\
\text { puddled soil }\end{array}$ & 87 & 72.50 & 13 \\
\hline 4 & $\begin{array}{l}\text { Seed are soaked in water for } 24 \mathrm{~h} \& \text { incubation } \\
\text { in gunny bags for } 24-48 \mathrm{~h}\end{array}$ & 98 & 81.67 & 5 \\
\hline 5 & $\begin{array}{l}\text { Germination length of seeds should not be } \\
\text { more than } 1-2 \mathrm{~mm} \text { to avoid mechanical injury of } \\
\text { pre-germinated seeds and to ensure flow of } \\
\text { seeds with the drum seeder }\end{array}$ & 89 & 74.17 & 11 \\
\hline 6 & $\begin{array}{l}\text { Sowing of sprouted seed using drum seeder } \\
\text { with row to row spacing of } 20 \mathrm{~cm} \text { facilitates } \\
\text { good tillering }\end{array}$ & 85 & 70.83 & 14 \\
\hline 7 & $\begin{array}{l}\text { Weedicide is a must in direct sowing using } \\
\text { drum seeder in puddle fields }\end{array}$ & 99 & 82.50 & 4 \\
\hline 8 & $\begin{array}{l}\text { Thin layer of irrigation water is to be } \\
\text { maintained till the seeds germinate }\end{array}$ & 79 & 65.83 & 17 \\
\hline 9 & $\begin{array}{l}\text { Intermittent irrigation at every } 2 \text {-3days up to } \\
\text { P.I.stage enhances tillering }\end{array}$ & 84 & 70.00 & 15 \\
\hline 10 & $\begin{array}{l}\text { Use of drum seeder is easy to operate and } 3 a c \\
\text { can be sown in a day by one man labour }\end{array}$ & 97 & 80.83 & 6 \\
\hline 11 & $\begin{array}{l}\text { Drum seeder is a drudgery reducing tool, easy } \\
\text { to use, convenient and resulted in shift of work } \\
\text { of women to men }\end{array}$ & 100 & 83.33 & 2 \\
\hline 12 & $\begin{array}{l}\text { Sowing by drum seeder saves time and reduces } \\
\text { the crop period by } 7 \text { days }\end{array}$ & 94 & 78.34 & 8 \\
\hline 13 & Drum seeder reduces labour requirement & 88 & 73.34 & 12 \\
\hline 14 & $\begin{array}{l}\text { Saves irrigation water compared to } \\
\text { conventional method of transplanting }\end{array}$ & 100 & 83.33 & 2 \\
\hline 15 & $\begin{array}{l}\text { Net profit is more using drum seeder than } \\
\text { transplanting }\end{array}$ & 93 & 77.50 & 9 \\
\hline 16 & Germinated seed is filled upto $2 / 3^{\text {rd }}$ of the drum & 81 & 67.50 & 16 \\
\hline 17 & $\begin{array}{l}\text { Use of drum seeder helps in timely } \\
\text { sowing of crop }\end{array}$ & 90 & 75.00 & 10 \\
\hline
\end{tabular}


Table.3 Adoption of package of practices by rice growers on Drum seeded technology

\begin{tabular}{|c|c|c|c|c|c|c|c|}
\hline \multirow{3}{*}{$\begin{array}{l}\text { S. } \\
\text { No }\end{array}$} & \multirow[t]{3}{*}{ Recommended practice } & \multicolumn{6}{|c|}{ Extent of Adoption } \\
\hline & & \multicolumn{2}{|c|}{$\begin{array}{c}\text { Fully } \\
\text { Adopted }\end{array}$} & \multicolumn{2}{|c|}{$\begin{array}{l}\text { Partially } \\
\text { Adopted }\end{array}$} & \multicolumn{2}{|c|}{$\begin{array}{c}\text { Not } \\
\text { Adopted }\end{array}$} \\
\hline & & $\mathbf{F}$ & $\%$ & $\mathbf{F}$ & $\%$ & $\mathbf{F}$ & $\%$ \\
\hline $\mathbf{I}$ & Field Preparation & & & & & & \\
\hline 1 & Leveling the field with plank before sowing & 76 & 63.33 & 31 & 25.83 & 13 & 10.84 \\
\hline 2 & Well puddled \& levelled field & 65 & 54.17 & 44 & 36.67 & 11 & 9.16 \\
\hline 3 & $\begin{array}{l}\text { Leave the field for 1-2 days for settling of } \\
\text { puddled soil }\end{array}$ & 54 & 45.00 & 50 & 41.67 & 16 & 13.33 \\
\hline 4 & Draining out excess water before sowing & 59 & 49.17 & 41 & 34.17 & 20 & 16.66 \\
\hline II & Seed sowing & & & & & & \\
\hline 1 & Seed rate $12-15 \mathrm{~kg} / \mathrm{ac}$ & 84 & 70.00 & 25 & 20.83 & 11 & 9.17 \\
\hline 2 & Seed treatment & 52 & 43.33 & 28 & 23.33 & 40 & 33.34 \\
\hline 3 & $\begin{array}{l}\text { Seed are soaked in water for } 24 \mathrm{~h} \& \\
\text { incubation in gunny bags for } 24-48 \mathrm{~h}\end{array}$ & 65 & 54.17 & 37 & 30.83 & 18 & 15.00 \\
\hline 4 & $\begin{array}{l}\text { Pre-germinated paddy seed are sown with } \\
\text { drum seeder }\end{array}$ & 79 & 65.83 & 31 & 25.83 & 10 & 8.34 \\
\hline 5 & $\begin{array}{l}\text { Germination length of seeds should not be } \\
\text { more than } 1-2 \mathrm{~mm} \text { to avoid mechanical injury } \\
\text { of pre-germinated seeds }\end{array}$ & 49 & 40.83 & 44 & 36.67 & 27 & 22.50 \\
\hline 6 & $\begin{array}{l}\text { Germinated seed is filled upto } 2 / 3^{\text {rd }} \text { of the } \\
\text { drum }\end{array}$ & 74 & 61.67 & 32 & 26.67 & 14 & 11.66 \\
\hline IIII & Weeding & & & & & & \\
\hline 1 & Application of pre-emergence herbicide & 55 & 45.83 & 42 & 35.00 & 23 & 19.17 \\
\hline 2 & Herbicide application 3-5days after sowing & 71 & 59.17 & 39 & 32.50 & 10 & 8.33 \\
\hline 3 & $\begin{array}{l}\text { Application of post- emergence herbicide } 20- \\
\text { 25days after sowing }\end{array}$ & 64 & 53.33 & 37 & 30.83 & 19 & 15.84 \\
\hline 4 & Weeding with conoweeder or power weeder & 30 & 25.00 & 39 & 32.50 & 51 & 42.50 \\
\hline IV & Agronomic practices & & & & & & \\
\hline 1 & $\begin{array}{l}\text { Basal dose of nitrogen fertilizer application } \\
\text { has to be made 15DAS to suppress weed } \\
\text { growth }\end{array}$ & 47 & 39.17 & 41 & 34.16 & 32 & 26.67 \\
\hline 2 & $\begin{array}{l}\text { Thin layer of irrigation water is to be } \\
\text { maintained till the seeds germinate }\end{array}$ & 41 & 34.17 & 51 & 42.50 & 28 & 23.33 \\
\hline 3 & $\begin{array}{l}\text { Intermittent irrigation at every 2-3days up to } \\
\text { P.I.stage to enhance tillering }\end{array}$ & 39 & 32.50 & 54 & 45.00 & 27 & 22.50 \\
\hline \multirow[t]{2}{*}{4} & Pest and disease management & 61 & 50.83 & 45 & 37.50 & 14 & 11.67 \\
\hline & & 59 & 49.30 & 39 & 32.91 & 22 & 17.79 \\
\hline
\end{tabular}

F-Frequency; \%- Percentage 
Table.4 Extent of adoption of recommended practices by Rice farmers $\quad \mathrm{N}=120$

\begin{tabular}{|l|l|l|c|c|}
\hline S.no & Category & Criteria \& Score & Frequency & Percentage \\
\hline $\mathbf{1}$ & Low level of adoption & $<\mathrm{x}-1 / 2 \mathrm{SD}(<17.77)$ & 21 & 17.50 \\
\hline $\mathbf{2}$ & Medium level of adoption & $<\mathrm{x} \pm 1 / 2 \mathrm{SD}(<17.78-32.91)$ & 39 & 32.50 \\
\hline $\mathbf{3}$ & High level of adoption & $>\mathrm{x}+1 / 2 \mathrm{SD}(>32.91)$ & 60 & 50.00 \\
\hline
\end{tabular}

$\mathrm{x}$ - no. of observations; S.D. - Standard deviation

Table.5 Benefits of drum seeder technology in Rice crop $\quad \mathrm{N}=120$

\begin{tabular}{|l|l|c|c|}
\hline $\begin{array}{l}\text { S. } \\
\text { no }\end{array}$ & Benefits of Drum seeder technology in Rice crop & Frequency & Percentage \\
\hline $\mathbf{1}$ & Yield is more than conventional transplanting & 98 & 81.66 \\
\hline $\mathbf{2}$ & $\begin{array}{l}\text { Saving in irrigation water, seed, labour \& } \\
\text { production costs }\end{array}$ & 95 & 79.16 \\
\hline $\mathbf{3}$ & Higher net economic returns & 84 & 70.00 \\
\hline $\mathbf{4}$ & Low input demand & 77 & 64.16 \\
\hline $\mathbf{5}$ & Less drudgery, early crop maturity by 7-10 days & 103 & 85.83 \\
\hline
\end{tabular}

Table.6 Problems experienced by the Rice farmers in adoption of Drum seeder technology

$\mathrm{N}=120$

\begin{tabular}{|l|l|c|c|}
\hline S. no & $\begin{array}{l}\text { Problems experienced by the Farmers in } \\
\text { adoption of Drum seeder technology }\end{array}$ & Frequency & Percentage \\
\hline $\mathbf{1}$ & Uneven and poor crop stand & 101 & 82.50 \\
\hline $\mathbf{2}$ & Poor weed control \& High weed infestation & 95 & 84.16 \\
\hline $\mathbf{3}$ & Crop lodging & 85 & 79.16 \\
\hline $\mathbf{4}$ & Poor knowledge of water \& nutrient management & 65 & 54.17 \\
\hline $\mathbf{5}$ & Depletion of organic matter content & 78 & 65.00 \\
\hline $\mathbf{6}$ & Rice varieties used for drum seeding are suitable & & \\
\hline $\mathbf{7}$ & for transplanted rice & 75 & 62.50 \\
\hline $\mathbf{8}$ & Pvailability of drum seeders & 72 & 60.00 \\
\hline $\mathbf{9}$ & Damage due to birds at germination stage & 68 & 56.67 \\
\hline $\mathbf{1 0}$ & Rains immediately after sowing in Kharif & 73 & 60.83 \\
\hline
\end{tabular}


Table.7 Suggestions to overcome the problems expressed by the rice farmers $\quad \mathrm{N}=120$

\begin{tabular}{|l|l|c|c|}
\hline S. no & Suggestions to overcome the problems & Frequency & Percentage \\
\hline $\mathbf{1}$ & $\begin{array}{l}\text { Development of varieties suitable for drum } \\
\text { seeder technology }\end{array}$ & 95 & 79.16 \\
\hline $\mathbf{2}$ & Proper sowing time & 88 & 73.34 \\
\hline $\mathbf{3}$ & Optimum seed rate & 91 & 75.83 \\
\hline $\mathbf{4}$ & $\begin{array}{l}\text { Technical knowledge on Weed \& water } \\
\text { management }\end{array}$ & 99 & 82.50 \\
\hline $\mathbf{5}$ & Use of suitable herbicides for weed control & 96 & 80.00 \\
\hline
\end{tabular}

It is inferred from Table no 5 that nearly 85.83 percent of the rice farmers felt that drum seeder technology involves less drudgery, early crop maturity by 7-10 days and 81.66 percent envisaged that yield is more in drum seeder technology than in conventional transplanting, 79.16 percent of the farmers suggested that there is saving in irrigation water, seed, labour \& production costs, 70.00 percent opined that they received higher net economic returns than conventional transplanting and 64.16 percent told that drum seeder technology involves low input demand as the benefits of drum seeding in rice. The results are in uniformity with the results of Chinnam Naidu D., et al., (2018) and Sahana S., et al., (2017).

The above results shows that lot of awareness has been created on the advantages of ploughing, levelling, seed germination, sowing, water and weed management in direct seeding rice using drum seeder in puddle field. Hence more than 50.00 percent of the farmers indicated that drum seeding in paddy is beneficial with some constraints.

It can be concluded from Table 6 that major problems expressed by 84.16 percent of the drum seeding practicing farmers was Poor weed control \& High weed infestation in the fields. This may be due to ignorance of the farmers on availability of latest weedicides in the market.
Uneven and poor crop stand was mentioned as the problem by 82.50 percent of the selected sampled farmers, this may be due to improper leveling of the field. 79.16 percent revealed that crop lodging as the major problem especially when strong gales are prevalent during cyclones. Poor knowledge of water \& nutrient management was given as the major problem by 70.83 percent of the growers and they felt that it was directly impacting their yields. Further 65.00 percent of the respondents opined that Rice varieties used for drum seeding are most suitable for transplanted rice compared to drum seeding. These findings are in conformity with Chinnam Naidu D., et al., (2018).

It is clear from Table 7 that major suggestion given by 82.50 percent of the rice farmers was to provide technical knowledge on weed \& water management followed by use of suitable herbicides for weed control by 80.00 percent, Development of varieties suitable for drum seeder technology by 79.16 percent, use of optimum seed rate by 75.83 percent and proper sowing time by 73.34 percent of the rice growers.

In conclusion, direct seeding of rice was a common practice before green revolution in India and is becoming popular once again because of its potential to save water and labour. However, high weed infestation is the major bottleneck in DSR, especially in dry field conditions and availability of several 
nutrients including $\mathrm{N}, \mathrm{P}, \mathrm{S}$ and micronutrients such as $\mathrm{Zn}$ and Fe, is likely to be a constraint.

It was very interesting to find from the study that nearly 85.00 percent of the farmers were interested to continue direct sowing in paddy in the coming seasons. This may be due to scarcity of the labour during peak agricultural operations, less dependence on labour, less cost of cultivation and relatively higher yields. Comprehensive and holistic efforts of KVK, Wyra and its technical support to the department of agriculture in promoting direct sowing paddy through front line demonstrations has created significant change at farmer's level in paddy cultivation. The present study had clearly indicated the superiority of direct sowing paddy using drum seeder as a sustainable method of rice cultivation.

The present finding shows that lot of awareness has to be created on levelling, seed germination, sowing, water and weed management in direct seeding rice using drum seeder in puddle field. Future thrust to upscale adoption of direct seeding rice is by large scale supply of drum seeders, power weeders, organizing training programmes involving department of agriculture and NGO's in promotional activities.

Broadcasting of pre-germinated paddy in a puddled field results non-uniformity in plant stand and difficulty in adopting the improved intercultural tools for weeding. Hence, it is vital to develop a mechanized direct sowing rice method that allows improved intercultural tools for weeding. Mechanization in paddy cultivation is becoming need of an hour in view of the escalating wages of the farm labour and their scarcity particularly in the peak period of transplanting, harvesting and threshing. Paddy cultivation is a laborious task and needs huge amount of labour from sowing to harvest. In order to reduce the risk on human labour, there is a need to go for mechanization and adequate farm power is needed for increasing paddy production by timely completion of farm operations.

Mechanization is the need of the hour in agriculture. Mechanization helps improvement in the quality and value addition of the produce and also enabling the farmers to raise a second crop or multicrop making the Indian agriculture attractive and a way of life by becoming commercial instead of subsistence and making the farming agreeable vocation for educated youth as well. There is a need to double the food production by 2020 to feed ever-increasing population in the country from same or shrinking land resources. This will call for raising more crops in a year, which demands availability of adequate power for timely farm operations, so that land is made available for subsequent crop. Increased production will require better management of inputs and natural resources and efficient management of crops through protection of crops from various stresses. This will call for greater mechanization inputs which will require developments and introduction of high capacity, precision, reliable and energy efficient equipment. Mechanization will help in boosting the technology and making it more viable for wider adoption among the farming community.

Extension activities can play very important role in popularization of DSR, which includes training, demonstration of DSR in farmer's field, on farm trials related to various potential problems faced by farmers and exposure visit of farmers to field. Improved short duration and high yielding varieties, nutrient and weed management techniques may encourage the farmers to shift from traditional system of transplanting to Drum seeder technology and also for improving the productivity of direct seeded 
rice an integrated approach should be undertaken to minimise the yield gap between direct seeded rice and transplanted rice. Coordination is also required within the different disciplines/specializations, between institutions and departments as well as functional areas like research, extension and training along with people's participation and new thrust on participatory research and development to bring farmers in the framework of interactions at all levels. Further, assistance is necessary for the farmers to adopt this technology and it warrants detailed investigations on direct seeding with respect to seed rate, spacing, varietal suitability, weed management, land preparation and other management aspects.

\section{References}

Annual report 2018-19, 2019. Department of Agriculture, Cooperation \& Farmers Welfare, Ministry of Agriculture \& Farmers Welfare, Government of India. Krishi Bhavan.

Aswini GK, Swain S and Debaraj B 2009. Effect of seedling age on performance of rice transplanter. Agricultural Mechanization in Asia, Africa and Latin America, 40(3): 41-46.

Chinnam Naidu D., et al., (2018) Adoption of Recommended Practices of Drum Seeder Technology in Paddy in North Coastal Andhra Pradesh. International Journal of Agriculture Sciences, ISSN: 0975-3710 \& E-ISSN: 0975-9107, Volume 10, Issue 24, pp.- 7628-7630.

Gangwar KS and Pandey DK, 2007. Aerobic rice- based cropping systems for higher productivity and profitability. Indian Farming, November 2007, pp. 3-6.

Jha, A. K.; Singh, K.M.;Meena, M. S. and Singh, R. K. P., (2012). Constraints of Rainfed Rice Production in Eastern India: An Overview. Available at http://dx.doi.org/10.2139/ssrn.2061953
Joshi, E., Dinesh Kumar, D., Lal, B., Nepalia, V., Gautam, P., and Vyas, A.K. (2013). Management of direct seeded rice for enhanced resource - use efficiency Plant Knowledge Journal 2(3):119-134

Joshi PK, Acharya SS, Chand Ramesh and Kumar Anjani, (2009).Agricultural Sector: Status and Performance. In: State of Indian Agriculture (Rai M et al., Eds.), National Academy of Agricultural Sciences, New Delhi India, pp. 1-34.

Kumar V, Ladha J.K (2011) Direct seeded rice: Recent development \& future research needs. Adv Agron. 111:297413

Naidu GJ, Rao KT, Rao AU and Reddy DS 2013. Age of seedling and planting pattern on grain yield, protein content, NPK uptake and post-harvest nutrient status of rice under SRI. J. Acad. Indust. Res., 2 (6): 334-337.

Nirmala, B. and P. Muthuraman (2009). Economic and Constraint Analysis of Rice Cultivation in Kaithal District of Haryana. Indian Research Journal of Extension Education, 9(1) : 47-49.

Negalur, R.B. and Halepyati, A.S. 2017. Growth and Yield of Machine Transplanted Rice (Oryza sativa L.) as Influenced by Age and Number of Seedlings. Int.J.Curr.Microbiol.App.Sci. 6(6): 376-385.

Pandey S,Mortimer M, Eade L, Tuong TP, Lopez K and Hardi B (Eds.). 2003. Direct seeding: research strategies and opportunities. Los Banos (Philippines): International Rice Research Institute, pp. 3-14.

Pandey S and Velasec L, 2002. Economics of direct seeding in Asia; Pattern of adoption and research priorities.

Pathak H, Ladha JK, Aggarwal PK, Peng S, Das S, Yadvinder Singh, Bijay-Singh, Kamra SK, Mishra B, Sastri ASRAS, Aggarwal HP, Das DK and Gupta RK, 
(2003). Climatic potential and onfarm yield trends of rice and wheat in the Indo- Gangetic plains. Field Crops Research 80: 223-234.

Pathak H, Singh R, Bhatia A and Jain N, 2006. Recycling of rice straw to improve crop yield and soil fertility and reduce atmospheric pollution. Paddy Water Environment 4: 111-117.

Raji RJ, Muthiah $\mathrm{M}$ and Arunachalam R 1996. Relationship between knowledge and adoption behaviour of trained and untrained farmers with their sociopersonal characteristics. Journal of extension education 7: 1304-1306.

Ramesh P and Govind S. 2008. Extent of adoption and relationship between the characteristics of organic farmers and their adoption level. Mysore Journal of Agricultural sciences 42(3): 526-529.

Rao AN, Johnson DE, Sivaprasad B, Ladha JK and Mortimer AM,2007. Weed management in direct-seeded rice. Advances in Agronomy 93: 153-255.

Sahana S., et al., (2017) Adoption and Attitude of the Farmers on Mechanization of Paddy in Command Areas of Karnataka. International Journal of Agriculture Sciences, ISSN: 0975-3710 \& E-ISSN: 0975-9107, Volume 9, Issue 29, pp.-4382-4384.

Singh, K.M. and Jha, A. K. and Meena, M. S. and Singh, R. K. P., (2012). Constraints of Rainfed Rice Production in India: An
Overview. In: Innovations in Rice Production, Ed: P.K. Shetty, M.R. Hegde and M. Mahadevappa, National Institute of Advance Studies, Indian Institute of Science, Bangalore, pp. 7184, 2012. Available at http://dx.doi.org/10.2139/ssrn.2210401

Singh, K.M. and Meena, M. S., (2012). Conservation Agriculture: Economic Perspective and Future Challenges. Available at http://dx.doi.org/10.2139/ssrn.2026336

Singh V and Ladha JK, 2011. Direct seeding of rice: Recent developments and future research needs. Advances in Agronomy 11: 297-413.

Subbaiah SV, Kumar RM and Mishra B, 2002. Modern Agronomic Techniques to increase rice production. Indian Farming 2002,pp. 7-12.

Suneetha, K. and Nagendra I. Kumar (2013). Cost and returns structure of paddy in Andhra Pradesh. Indian Journal of Research, 3(5) : $40-42$.

Vasudevan SN, Basangouda, Mathad RC, Doddagoudar SR and Shakuntala NM 2014. Standardization of Seedling Characteristics for Paddy Transplanter. Journal of Advanced Agricultural Technologies 1(2), 141-146.

Visalakshi M and Sireesha A 2016. Adoption Status of Direct Seeding Rice using Drum Seeder. Journal of Rice Research 2016, Vol 9 No. 1, 30-34.

\section{How to cite this article:}

Raja Madhu Shaker, B., J. Hemantha Kumar, P. Jagan Mohan Rao, P. Sri Ranjitha, V. Chaitanya and Ravi Kumar, K. 2020. Knowledge and Adoption Levels of the Farmers on Direct Seeding among Rice Farmers of Khammam District of Telangana State, India. Int.J.Curr.Microbiol.App.Sci. 9(06): 1877-1887. doi: https://doi.org/10.20546/ijcmas.2020.906.233 